\title{
THE EFFECT OF CATALYST SUPPORT ON THE DECOMPOSITION OF METHANE TO HYDROGEN AND CARBON
}

\author{
SHARIF HuSSEIN SHARIF ZEIN AND AbDul RAHMAN MOHAMED* \\ School of Chemical Engineering, Engineering Campus, Universiti Sains Malaysia, Seri \\ Ampangan, 14300 Nibong Tebal, S.P.S, Pulau Pinang, Malaysia \\ *e-mail: chrahman@eng.usm.my
}

\begin{abstract}
Decomposition of methane into carbon and hydrogen over $\mathrm{Cu} / \mathrm{Ni}$ supported catalysts was investigated. The catalytic activities and the lifetimes of the catalysts were studied. $\mathrm{Cu} / \mathrm{Ni}$ supported on $\mathrm{TiO}_{2}$ showed high activity and long lifetime for the reaction. Transmission electron microscopy (TEM) studies revealed the relationship between the catalyst activity and the formation of the filamentous carbon over the catalyst after methane decomposition. While different types of filamentous carbon formed on the various $\mathrm{Cu} / \mathrm{Ni}$ supported catalysts, an attractive carbon nanotubes was observed in the $\mathrm{Cu} / \mathrm{Ni}$ supported on $\mathrm{TiO}_{2}$.
\end{abstract}

Key Words: Methane decomposition, carbon nanotube, Cu/Ni supported catalysts.

\section{INTRODUCTION}

All conventional options of hydrogen production from natural gas, mainly methane e.g., steam reforming, partial oxidation, and autothermal reforming, involve $\mathrm{CO}_{2}$ production at some point in the technological chain of the process.

Another approach is to decompose methane into hydrogen and carbon. It is a technologically simple one-step process without energy and material intensive gas separation stages and shows the potential to be a $\mathrm{CO}_{2}$-free hydrogen production process [1]. Although the decomposition of methane over metal-oxide transition metal catalysts produces high initial hydrogen concentration, their activity rapidly drops because of the surface deposition of carbon. However, the generally accepted mechanism of the growth of carbon nanotube proved that this kind of carbon deposition occurs without encapsulating of the metal surfaces, hence, maintaining the catalyst activity for a period of a time. Thus, efficient catalyst for methane decomposition could be developed when the condition of filamentous carbon growth are provided.

$\mathrm{Cu} / \mathrm{Ni}$ is known as one of the active catalysts in methane decomposition [2-5]. When active metal species are deposited on different supports, it is generally accepted that the catalytic performance of metal species depends on the types of supports. This can be attributed to the change of the structure or electronic state of the metal species due to the 
interaction with the supports [6]. It is also reported that methane decomposition depend on type of support and this might be the case with which carbon migration occurred from metal support [7]. Therefore, it is worth examining the best support and its combination of the active component in order to design a catalyst having a high catalytic performance for the decomposition of methane. The objective of this study is to identify the effect of $\mathrm{Cu} / \mathrm{Ni}$ supported on $\mathrm{MgO}, \mathrm{Al}_{2} \mathrm{O}_{3}, \mathrm{TiO}_{2}$, and $\mathrm{SiO}_{2}$ towards methane decomposition to hydrogen and carbon.

\section{EXPERIMENTAL}

The catalysts used in this study were $15 \mathrm{~mol} \% \mathrm{CuO} / 20 \mathrm{~mol} \% \mathrm{NiO}$ catalyst supported on $\mathrm{MgO}, \mathrm{Al}_{2} \mathrm{O}_{3}, \mathrm{TiO}_{2}$, and $\mathrm{SiO}_{2}$. The catalysts were prepared using impregnation method. The experiments were carried out at atmospheric pressure in a stainless steel fixed bed reactor system. A schematic diagram of the reactor system is shown in Fig. 1. The reactor was fabricated from a stainless steel tube (O.D. $12.7 \mathrm{~mm}$, I.D. $10.92 \mathrm{~mm}$ and $600 \mathrm{~mm}$ length). A thermocouple of type $\mathrm{K}$ in an inconel tube, with $3 \mathrm{~mm}$ diameter and $600 \mathrm{~mm}$ long was used to measure the temperature of the catalyst bed in the reactor. The catalyst layer was situated in the centre of the reactor. The free space before and after the catalyst layer was filled with quartz particles (RDH) in order to minimize the reactor dead volume. Furnace used was a single zone (model Carbolite VST 11) with temperature controller and was supplied by Carbolite, U.K. A pressure gauge (Ashcroft, USA) located just above the reactor was used to read the inlet pressure.

Methane (supplied by Malaysian Oxygen Sdn. Bhd.) with $99.999 \%$ purity and argon (supplied by Sitt Tatt Industrial Gasses Sdn Bhd.) with $99.999 \%$ purity were mixed before entering the reactor. Argon was used as a diluent gas as nitrogen might react with the hydrogen at high temperatures. Flow of methane was regulated using a mass flow controller (MKS) and argon flow was regulated by Brooks mass flow controller (model $5850 \mathrm{E}$ ). Outlet gas flow was monitored by a gas flow meter (Alexander Wright DM3 B).

The product gases were analyzed using an on-line Gas Chromatograph (GC) (HewlettPackard Series 6890, USA). The GC was controlled on-line using HP ChemStation Rev. A. 06.01. [403] software. Porapaq N and Molecular Sieve $5 \AA$ (1/8" diameter, 6 feet long length) stainless steel columns, situated in a series with the Porapaq $\mathrm{N}$ column located in front were used. The Porapaq $\mathrm{N}$ column was used to separate carbon dioxide, ethane, ethylene and propylene and the Molecular Sieve $5 \AA$ column for hydrogen, oxygen, carbon monoxide, nitrogen and methane. Since higher hydrocarbons and carbon dioxide can ruin the Molecular Sieve $5 \AA$ column, two valves operated at $333 \mathrm{~K}$ were used to control the outlet gas from the Porapaq $\mathrm{N}$ column to the detectors while avoiding passing through the Molecular Sieve $5 \AA$. Valve 1 functioned as sampling mechanism and valve 2 to control the flow of the product through the Molecular Sieve $5 \AA$ column. When one of the valve is turned off, it indicates that the gas is allowed to flow through the Molecular Sieve $5 \AA$ column. The gas chromatograph injector temperature was set at $313 \mathrm{~K}$. The initial and the final temperature of the oven were set at 313 and $473 \mathrm{~K}$, respectively. A heating rate of 5 $\mathrm{K} / \mathrm{min}$ was used. The detector temperature was kept at $473 \mathrm{~K}$. Pure argon gas (99.999\%) was used as a carrier gas. The total analysis time was 25 minutes for each injection. Standard gas was injected into the gas chromatograph and the area of each of the component in the standard gas was determined. The standard gas mixture was supplied by 
BOC Gases, UK. Chromatogram of hydrocarbons such as methane, ethylene, ethane, and propylene were obtained using a flame ionization detector (FID) whereas hydrogen, oxygen, carbon monoxide and carbon dioxide were detected using thermal conductivity detector (TCD).

Pore size and surface area measurements of the different samples were determined via nitrogen adsorption/desorption isotherms at liquid nitrogen temperature $(77 \mathrm{~K})$ using an Automated Gas Sorption System, (Autosorb I, QuantoChrome Corporation, USA). All samples were degassed at a temperature of $573 \mathrm{~K}$ for 3 hours prior to the measurements. Computer programs (Micropore version 2.46) allowed for rapid numerical results for the surface area and pore texture from adsorption-desorption isotherm. X-ray diffraction refined by Reitfield method was used to characterize the catalyst structure. Roomtemperature XRD was conducted on a Siemen D-5000 diffractometer, using CuK $\alpha$ radiation, and a graphite secondary beam monochromator. Specimen was prepared by packing sample powder in a glass holder. Intensity was measured by step scanning in the $2 \theta$ range between $10-90^{\circ}$, with a step of $0.02^{\circ}$ and a measuring time of 2 second per point. The diffraction lines of the XRD pattern were used to identify the formation of solid solution by comparing the $2 \theta$ values of the materials with those of phase from the powder diffraction files. Spent catalysts, covered with carbon were analyzed using a transmission electron microscope (Philips TEM CM12). In preparation for TEM experiments, a few samples of the spent catalyst were dispersed in distilled water, and then a drop was deposited on a coated copper grid. The conversion of methane and the yield of hydrogen are defined as follows:

$$
\begin{aligned}
& \text { Conversion }(\%)=\frac{\text { Mole of methane reacted }}{\text { Mole of methane input }} \times 100 \\
& \text { Yield }(\%)=\frac{\text { Mole of hydrogen produced }}{\text { Mole of methane input } \times 2^{*}} \times 100 \\
& { }^{*} \mathrm{CH}_{4} \rightarrow \mathrm{C}+2 \mathrm{H}_{2}
\end{aligned}
$$

\section{RESULTS AND DISCUSSION}

Thermal decomposition of methane converts methane to hydrogen and solid carbon at high temperatures. It is believed that methyl radicals polymerize to form cyclic and aromatic precursors to graphitic soot particles. However, the form of carbon produced by catalytic decomposition of methane depends on the catalyst used and the reaction parameters.

Table 1 shows the physical properties of the fresh $\mathrm{Cu} / \mathrm{Ni}$ supported on $\mathrm{TiO}_{2}, \mathrm{SiO}_{2}$, $\mathrm{MgO}$, and $\mathrm{Al}_{2} \mathrm{O}_{3}$, respectively. The surface area of the $\mathrm{Cu} / \mathrm{Ni}$ on $\mathrm{Al}_{2} \mathrm{O}_{3}, \mathrm{Cu} / \mathrm{Ni}$ on $\mathrm{MgO}$, $\mathrm{Cu} / \mathrm{Ni}$ on $\mathrm{SiO}_{2}$, and $\mathrm{Cu} / \mathrm{Ni}$ on $\mathrm{TiO}_{2}$ was $14.27,11.27,5.28$, and $4.79 \mathrm{~m}^{2} / \mathrm{g}$, respectively. The total pore volume shows the same trend as in the surface area and with the value of $0.009,0.008,0.004$, and $0.003 \mathrm{cc} / \mathrm{g}$ for the $\mathrm{Cu} / \mathrm{Ni}$ on $\mathrm{Al}_{2} \mathrm{O}_{3}, \mathrm{Cu} / \mathrm{Ni}$ on $\mathrm{MgO}, \mathrm{Cu} / \mathrm{Ni}$ on $\mathrm{SiO}_{2}$, and $\mathrm{Cu} / \mathrm{Ni}$ on $\mathrm{TiO}_{2}$, respectively. The $\mathrm{Cu} / \mathrm{Ni}$ on $\mathrm{MgO}$ had the largest pore diameter 
( $27 \AA$ ), while $\mathrm{Cu} / \mathrm{Ni}$ on $\mathrm{Al}_{2} \mathrm{O}_{3}$ and $\mathrm{Cu} / \mathrm{Ni}$ on $\mathrm{TiO}_{2}$ had average pore diameter $(\sim 26 \AA)$. The $\mathrm{Cu} / \mathrm{Ni}$ on $\mathrm{SiO}_{2}$ had the smallest average pore diameter $(\sim 24 \AA)$. This might be the change of the structure of the catalyst due to the support.

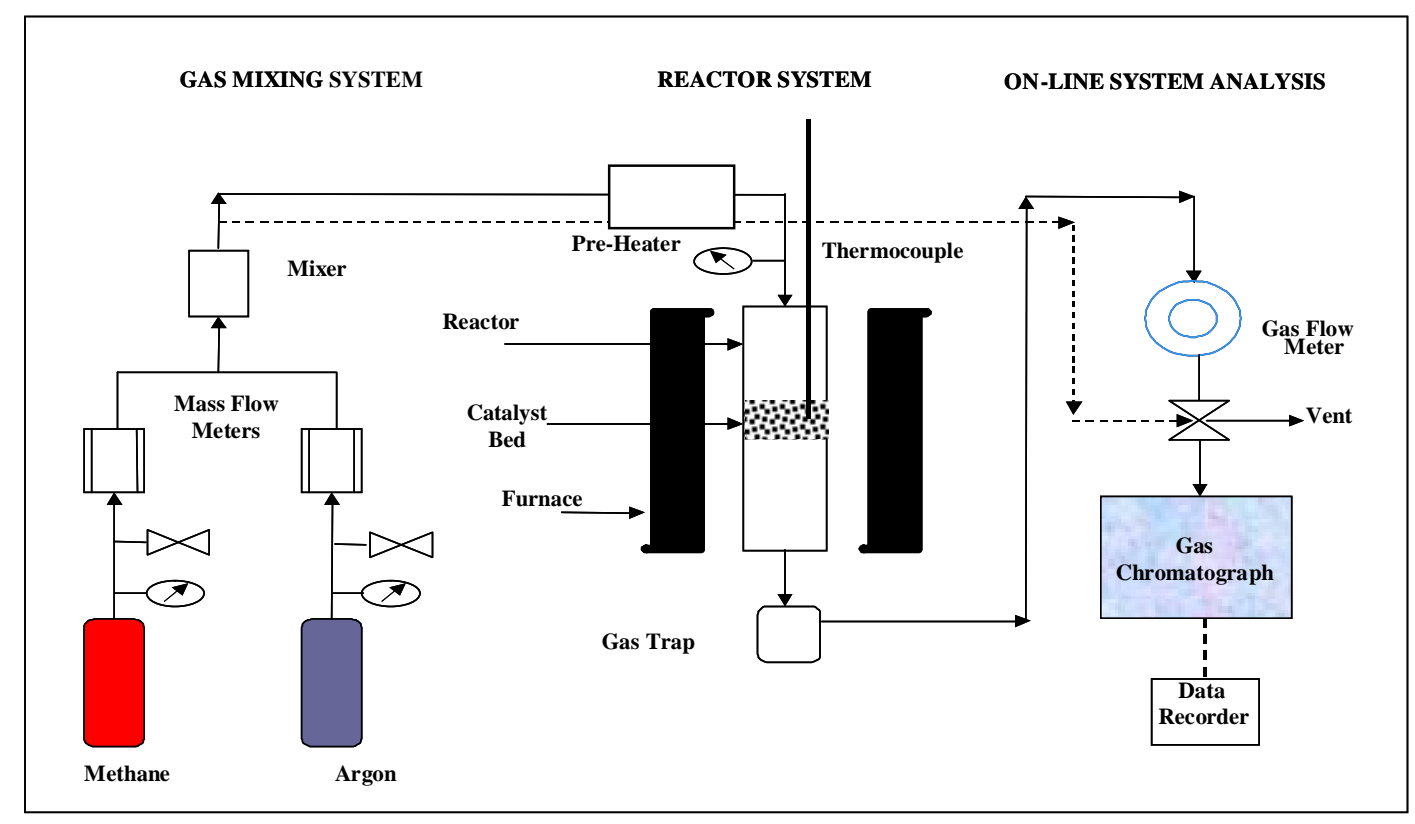

Fig. 1: Schematic diagram of the reactor system.

Table 1: The physical properties of the fresh $\mathrm{Cu} / \mathrm{Ni}$ supported on different supports.

\begin{tabular}{cccc}
\hline Catalyst & $\begin{array}{c}\text { Surface Area } \\
\left(\mathrm{m}^{2} / \mathrm{g}\right)\end{array}$ & $\begin{array}{c}\text { Total Pore Volume } \\
\left(\mathrm{V}_{\mathrm{p}}\right)(\mathrm{cc} / \mathrm{g})\end{array}$ & $\begin{array}{c}\text { Average Pore } \\
\text { Diameter }(\AA)\end{array}$ \\
\hline $\mathrm{Cu} / \mathrm{Ni}$ on $\mathrm{MgO}$ & 11.27 & 0.008 & 26.99 \\
$\mathrm{Cu} / \mathrm{Ni}$ on $\mathrm{Al}_{2} \mathrm{O}_{3}$ & 14.27 & 0.009 & 25.73 \\
$\mathrm{Cu} / \mathrm{Ni}$ on $\mathrm{TiO}_{2}$ & 4.79 & 0.003 & 26.07 \\
$\mathrm{Cu} / \mathrm{Ni}$ on $\mathrm{SiO}_{2}$ & 5.28 & 0.004 & 23.81 \\
\hline
\end{tabular}

Table 2 shows the performance of $\mathrm{Cu} / \mathrm{Ni}$ catalyst supported onto $\mathrm{TiO}_{2}, \mathrm{Al}_{2} \mathrm{O}_{3}, \mathrm{MgO}$, and $\mathrm{SiO}_{2}$ supports for methane dissociation to hydrogen and carbon at $998 \mathrm{~K}$ and gas hourly space velocity (GHSV) of $2700 \mathrm{~h}^{-1}$. Generally, methane decomposition proceeded over all the catalysts upon contact with the catalysts. The ratio of methane conversion and hydrogen formation was found to be in a ratio of 1:2. In fact, hydrogen was the only gas detected after five minutes on stream. The initial methane decomposition obtained within the first 5 minutes of reaction decreased in the order $\mathrm{SiO}_{2}>\mathrm{Al}_{2} \mathrm{O}_{3}>\mathrm{TiO}_{2}>\mathrm{MgO}$ support. 
These data should be relatively free of deactivation effects due to blocking of active sites by the decomposition products. After 60 minutes on stream, the order of activity changed to $\mathrm{TiO}_{2}>\mathrm{SiO}_{2}>\mathrm{MgO}$ support and pressure build up was observed on $\mathrm{Al}_{2} \mathrm{O}_{3}$ support. At 120 minutes on stream, the $\mathrm{TiO}_{2}$ system maintained its activity and the $\mathrm{MgO}$ decreased from $16 \%$ to $8 \%$ while pressure build up in the $\mathrm{SiO}_{2}$ supported catalyst system.

Table 2: The effect of the catalyst support on hydrogen production via catalytic decomposition of methane at $998 \mathrm{~K}\left(\mathrm{GHSV}=2700 \mathrm{~h}^{-1}\right)$.

\begin{tabular}{cccc}
\hline Catalyst & $\begin{array}{c}\text { Conversion }(\%) \& \\
\mathrm{H}_{2} \text { Yield }(\%)\end{array}$ & $\begin{array}{c}\text { Conversion (\%) } \\
\& \mathrm{H}_{2} \text { Yield }(\%)\end{array}$ & $\begin{array}{c}\text { Conversion (\%) \& } \\
\mathrm{H}_{2} \text { Yield (\%) }\end{array}$ \\
\hline $\mathrm{Cu} / \mathrm{Ni}$ on $\mathrm{MgO}$ & $5 \mathrm{~min}$ & $60 \mathrm{~min}$ & $120 \mathrm{~min}$ \\
$\mathrm{Cu} / \mathrm{Ni}$ on $\mathrm{Al}_{2} \mathrm{O}_{3}$ & 52 & 16 & 8 \\
$\mathrm{Cu} / \mathrm{Ni}$ on $\mathrm{TiO}_{2}$ & 73 & nd & nd \\
$\mathrm{Cu} / \mathrm{Ni}$ on $\mathrm{SiO}_{2}$ & 65 & 61 & 62 \\
\hline
\end{tabular}

nd $=$ Not determined. When the inlet pressure exceeds $1 \mathrm{~atm}$.

The methane decomposition over $\mathrm{Cu} / \mathrm{Ni}$ supported onto $\mathrm{TiO}_{2}, \mathrm{Al}_{2} \mathrm{O}_{3}, \mathrm{MgO}$, and $\mathrm{SiO}_{2}$ supports was significant, as can be seen from Table 2. This can be explained in terms of the relative magnitudes of the rate of methane decomposition and the rate of migration of the deposit from the metal to the support. It is assumed that the rate of methane decomposition decreases with increasing coverage while the rate of migration of the deposit from the metal to the support increases with coverage. Initially, the observed rate is determined by the rate of methane decomposition since all metal sites are vacant. However, as coverage of the active metal by carbonaceous deposit increases, the rate of migration of the deposit from the metal to the support is increased whereas the methane decomposition rate is decreased. When monolayer coverage is achieved, the observed rate is controlled by the rate of migration of the carbonaceous deposit from the metal to the support [8]. When the rate of migration at monolayer coverage is lower than the initial rate of decomposition and as coverage of metal increases, the rate controlling step changes from decomposition of methane to migration of the deposit from the metal to the support. Accordingly, as the carbonaceous species migrate from the metal to the support, metal sites are regenerated and further reaction can occur. Hence, the mobility of the carbonaceous deposit from the metal to the support must be an important factor. Thus, in the parameters studied, it was concluded that the carbonaceous deposit migrates onto support more readily for $\mathrm{TiO}_{2}>\mathrm{SiO}_{2}>\mathrm{MgO}>\mathrm{Al}_{2} \mathrm{O}_{3}$ support and the cumulative methane decomposition is therefore greater for $\mathrm{Cu} / \mathrm{Ni}$ supported on $\mathrm{TiO}_{2}>\mathrm{SiO}_{2}>\mathrm{MgO}>\mathrm{Al}_{2} \mathrm{O}_{3}$ support. 
The X-ray diffraction (XRD) profiles of the $\mathrm{Cu} / \mathrm{Ni}$ loaded on different supports are shown in Fig. 2 (a) - (d). As shown in Fig. 2 (a) and (b), the $\mathrm{Cu} / \mathrm{Ni}$ on $\mathrm{TiO}_{2}$ support and $\mathrm{Cu} / \mathrm{Ni}$ on $\mathrm{MgO}$ support contained $20 \mathrm{~mol} \% \mathrm{NiO}$, but large $\mathrm{NiO}$ particle was not observed on their XRD profiles, which indicated $\mathrm{NiO}$ on these two catalysts was highly dispersed. It is well known that $\mathrm{MgO}$ and $\mathrm{NiO}$ could form a solid solution due to very good mutual solubility between $\mathrm{MgO}$ and $\mathrm{NiO}$. This can be brought out by the results of XRD determination of the catalyst precursor $\mathrm{NiO}-\mathrm{MgO}$, in which does not have difference in comparison with that of the pure $\mathrm{MgO}$ and $\mathrm{NiO}$ phase but the crystal cell of this newly formed phase is between those of $\mathrm{NiO}$ and $\mathrm{MgO}$, perhaps implying the formation of $\mathrm{Ni}_{\mathrm{x}} \mathrm{Mg}_{1-\mathrm{x}} \mathrm{O}$ formation solid solution [9]. Since the $\mathrm{Cu} / \mathrm{Ni}$ on $\mathrm{TiO}_{2}$ support was more active than $\mathrm{Cu} / \mathrm{Ni}$ on $\mathrm{MgO}$ support, in this case the $\mathrm{Ni}^{+2}$ ions in the NiO-MgO system may be highly dispersed and evenly distributed in the lattice of $\mathrm{MgO}$ due to the mutual solubility between $\mathrm{NiO}$ and $\mathrm{MgO}$, so that the $\mathrm{Ni}$-component in the $\mathrm{Ni}_{\mathrm{x}} \mathrm{Mg}_{1-\mathrm{x}} \mathrm{O}$ would be inactive in methane decomposition in the studied process. The $\mathrm{NiO}$ characteristic peaks $(2 \theta=37.4$, 43.4 and 63.1) were not observed. The characteristic peaks of $\mathrm{NiO}$ are obvious in the XRD spectrum of $\mathrm{Cu} / \mathrm{Ni}$ on $\mathrm{SiO}_{2}$ support catalyst which indicates that the $\mathrm{Ni}$ is comparatively inconsistently loaded on this support and its surface becomes rough (Fig. 2 (c)). This phenomenon is probably caused by sintering of the catalyst and is also responsible for the loss in catalytic activity. The XRD pattern of $\mathrm{Cu} / \mathrm{Ni}$ on $\mathrm{SiO}_{2}$ support revealed peaks at $2 \theta$ $=37.3,43.3$ and 62.9 indicated large crystal of $\mathrm{NiO}$ particles were formed [10]. The $\mathrm{Cu} / \mathrm{Ni}$ on $\mathrm{Al}_{2} \mathrm{O}_{3}$ support catalyst was found to be the least crystalline as shown in Fig. 2 (d). This might caused interaction between $\mathrm{Cu} / \mathrm{Ni}$ and the $\mathrm{Al}_{2} \mathrm{O}_{3}$ support. As a result, the catalyst was not stable during reaction.

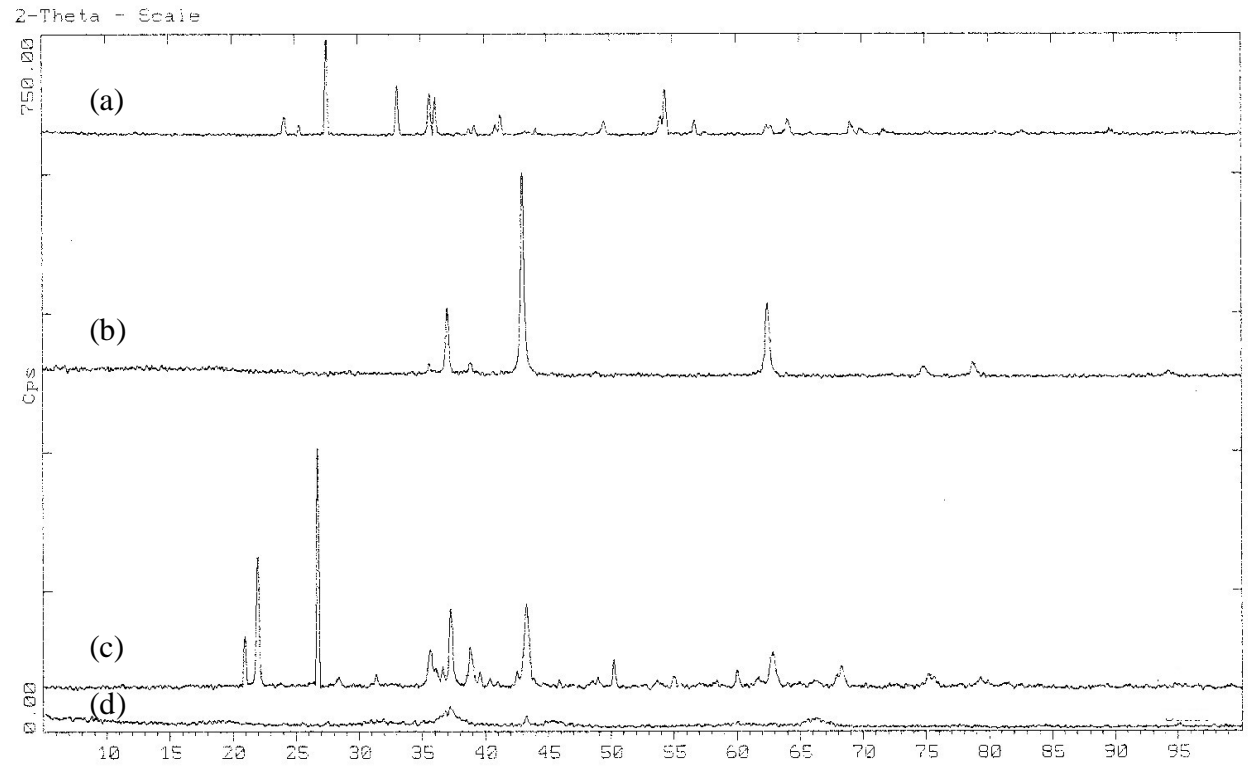

Fig. 2: The XRD pattern of the fresh catalyst containing $\mathrm{Cu} / \mathrm{Ni}$ supported on (a) $\mathrm{TiO}_{2}$, (b) $\mathrm{MgO}$, (c) $\mathrm{SiO}_{2}$, and (d) $\mathrm{Al}_{2} \mathrm{O}_{3}$.

Table 3 shows the physical properties of used $\mathrm{Cu} / \mathrm{Ni}$ catalysts supported on $\mathrm{TiO}_{2}, \mathrm{SiO}_{2}$, $\mathrm{MgO}$, and $\mathrm{Al}_{2} \mathrm{O}_{3}$. Carbon formation affected the physical properties of the catalysts. The 
surface area of the $\mathrm{Cu} / \mathrm{Ni}$ supported on $\mathrm{Al}_{2} \mathrm{O}_{3}, \mathrm{MgO}, \mathrm{SiO}_{2}$, and $\mathrm{TiO}_{2}$ was 24.38, 25.86, 22.10 , and $38.23 \mathrm{~m}^{2} / \mathrm{g}$, respectively. The total pore volume was $0.015,0.017,0.014$, and $0.025 \mathrm{cc} / \mathrm{g}$ for and the $\mathrm{Cu} / \mathrm{Ni}$ supported on $\mathrm{Al}_{2} \mathrm{O}_{3}, \mathrm{MgO}, \mathrm{SiO}_{2}$, and $\mathrm{TiO}_{2}$, respectively. The average pore diameter for the $\mathrm{Cu} / \mathrm{Ni}$ on $\mathrm{MgO}, \mathrm{Cu} / \mathrm{Ni}$ on $\mathrm{Al}_{2} \mathrm{O}_{3}$, and $\mathrm{Cu} / \mathrm{Ni}$ on $\mathrm{TiO}_{2}$ gave $26 \AA$. The $\mathrm{Cu} / \mathrm{Ni}$ on $\mathrm{SiO}_{2}$ had the smallest average pore diameter $(\sim 25 \AA)$.

Table 3: The physical properties of the used $\mathrm{Cu} / \mathrm{Ni}$ catalysts supported on different supports. These catalysts were used in the methane decomposition reaction at $998 \mathrm{~K}$ and GHSV of $2700 \mathrm{~h}^{-1}$.

\begin{tabular}{cccc}
\hline Catalyst & $\begin{array}{c}\text { Surface Area } \\
\left(\mathrm{m}^{2} / \mathrm{g}\right)\end{array}$ & $\begin{array}{c}\text { Total Pore Volume } \\
\left(\mathrm{V}_{\mathrm{p}}\right)(\mathrm{cc} / \mathrm{g})\end{array}$ & $\begin{array}{c}\text { Average Pore } \\
\text { Diameter }(\AA)\end{array}$ \\
\hline $\mathrm{Cu} / \mathrm{Ni}$ on $\mathrm{MgO}$ & 25.86 & 0.017 & 26.12 \\
$\mathrm{Cu} / \mathrm{Ni}$ on $\mathrm{Al}_{2} \mathrm{O}_{3}$ & 24.38 & 0.015 & 25.89 \\
$\mathrm{Cu} / \mathrm{Ni}$ on $\mathrm{TiO}_{2}$ & 38.23 & 0.025 & 25.76 \\
$\mathrm{Cu} / \mathrm{Ni}$ on $\mathrm{SiO}_{2}$ & 22.01 & 0.014 & 25.12 \\
\hline
\end{tabular}

Carbon samples obtained on $\mathrm{Cu} / \mathrm{Ni}$ catalysts loaded into various supports were further studied using TEM. The result obtained elucidated that introduction of the support influence the carbon morphology remarkably. The TEM micrograph of carbon synthesized on $\mathrm{Cu} / \mathrm{Ni}$ on $\mathrm{MgO}$ support is shown in Fig. 3. It looks like small tubes connected to each other. Figure 4 shows the TEM images of the carbon synthesized on $\mathrm{Cu} / \mathrm{Ni}$ on $\mathrm{Al}_{2} \mathrm{O}_{3}$ support. A major part of the carbon looks like short and broken small tubes and are free of metal particles, and only empty ends of tubes are seen in the micrographs. On the other hand, the TEM image of $\mathrm{Cu} / \mathrm{Ni}$ on $\mathrm{SiO}_{2}$ support shows that the carbon nanotube looks like not developed fully yet and also the presence of black spots which might be the sintered $\mathrm{NiO}$ particle (Fig. 5) although it has a catalyst particle at the tip of the carbon. The carbon formed using $\mathrm{Cu} / \mathrm{Ni}$ on $\mathrm{TiO}_{2}$ support catalyst (Fig. 6) was the best among the supported catalysts. It shows well developed long carbon nanotubes with a catalyst particle located at the tip of the carbon and clear image of the pore where reactants and the products can flow. Data presented above demonstrate that long-lived catalysts could be developed when the conditions of filamentous carbon growth are provided. Thus, the catalytic activity depended strongly the kind of support.

A mechanistic interpretation for the growth of carbon on the catalyst was proposed [11, 12]. The result in Fig. 5 support the proposed mechanism for the growth of carbon nanotube on the catalyst. Methane decomposes on the front surface of certain active sites of the $\mathrm{Cu} / \mathrm{Ni} / \mathrm{TiO}_{2}$ based catalyst and the carbon formed diffuses through the metal and precipitates at the rear surface. The driving force which pushed the carbon diffusion was suggested to originate from the concentration gradient of dissolved carbon between the two interfaces i.e. the metal-gas interface to the metal-nanocarbon interface. 


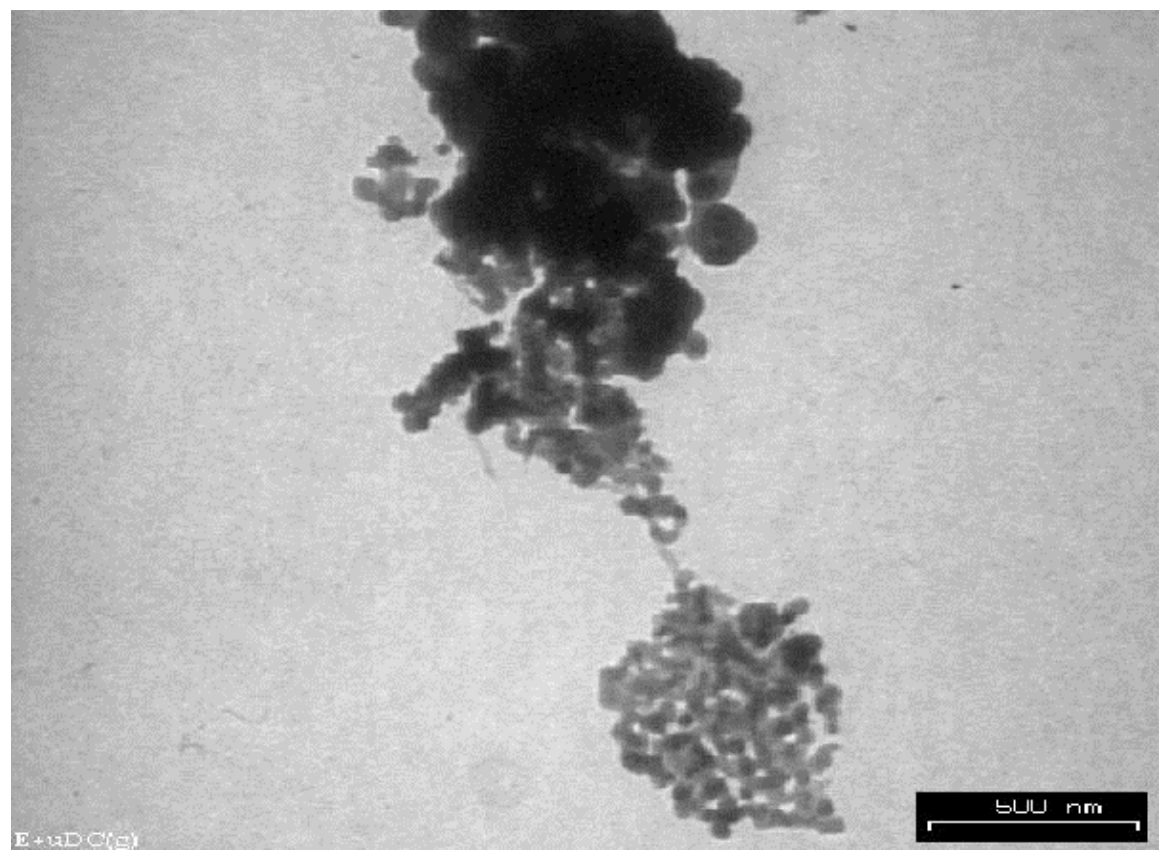

Fig. 3: The transmission electron microscope image of the nanotube produced on $\mathrm{Cu} / \mathrm{Ni}$ supported on $\mathrm{MgO}$ at $998 \mathrm{~K}$ and GHSV of $2700 \mathrm{~h}^{-1}$.

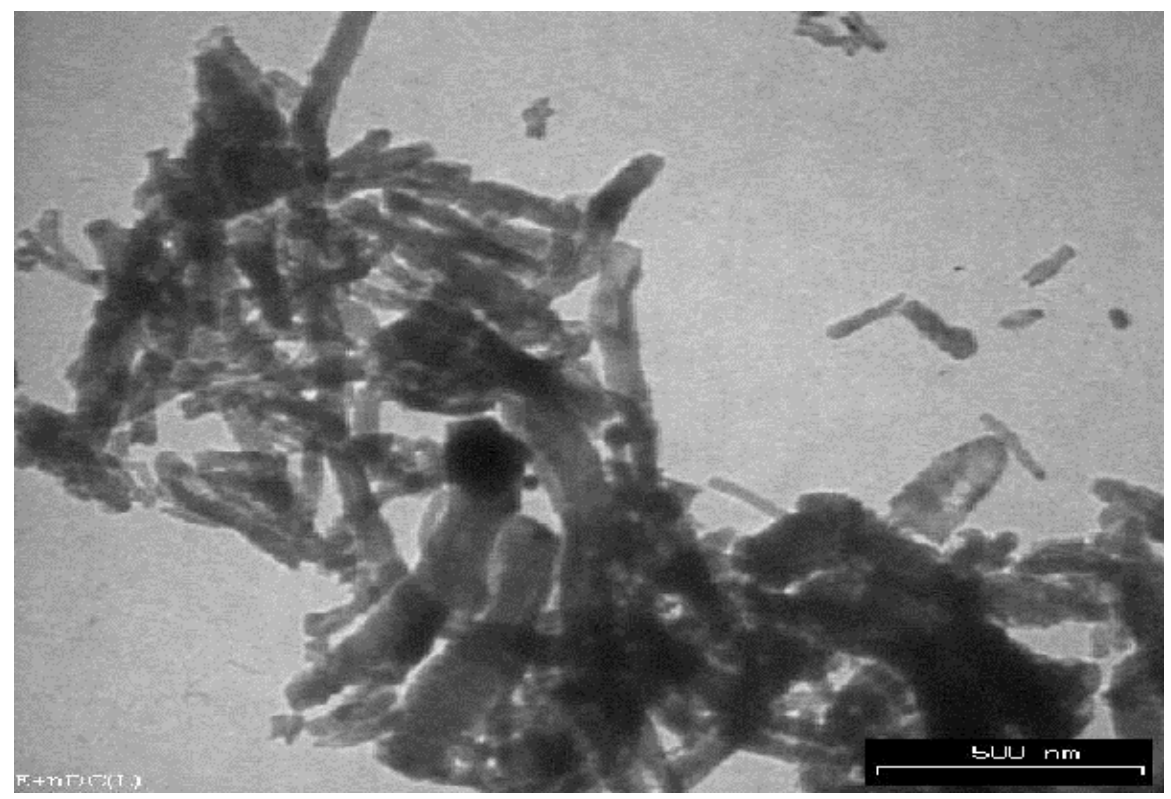

Fig. 4: The transmission electron microscope image of the nanotube produced on $\mathrm{Cu} / \mathrm{Ni}$ supported on $\mathrm{Al}_{2} \mathrm{O}_{3}$ at $998 \mathrm{~K}$ and $\mathrm{GHSV}$ of $2700 \mathrm{~h}^{-1}$. 


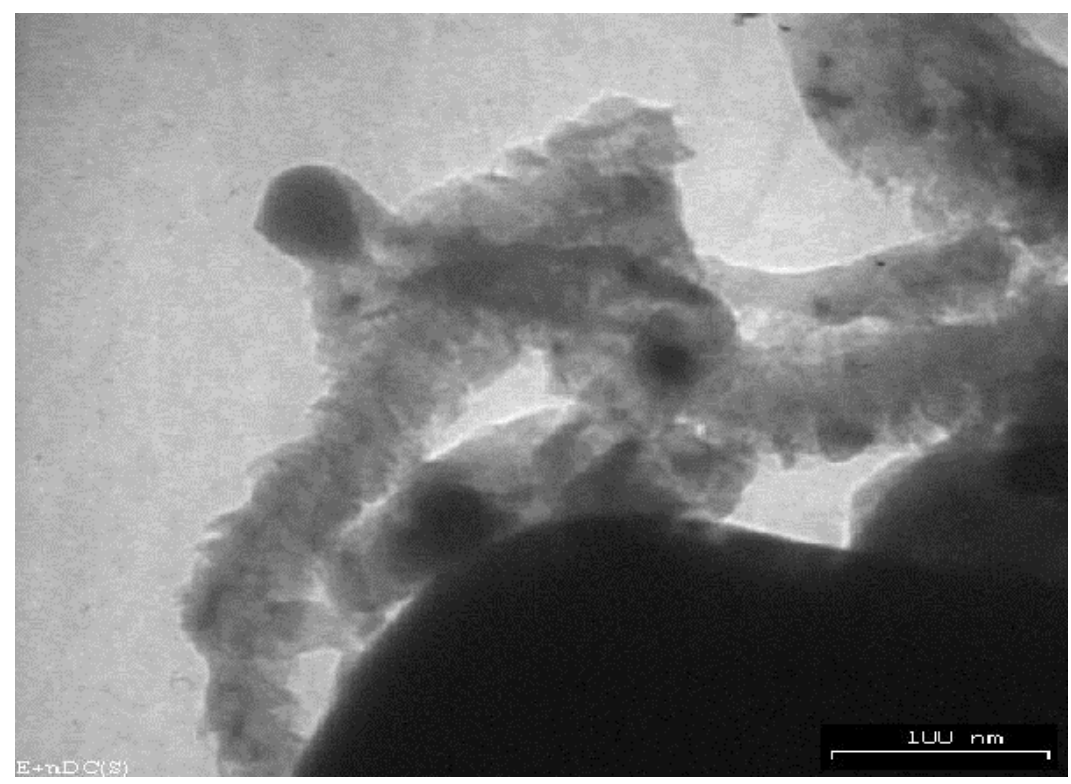

Fig. 5: The transmission electron microscope image of the nanotube produced on $\mathrm{Cu} / \mathrm{Ni}$ supported on $\mathrm{SiO}_{2}$ at $998 \mathrm{~K}$ and GHSV of $2700 \mathrm{~h}^{-1}$.

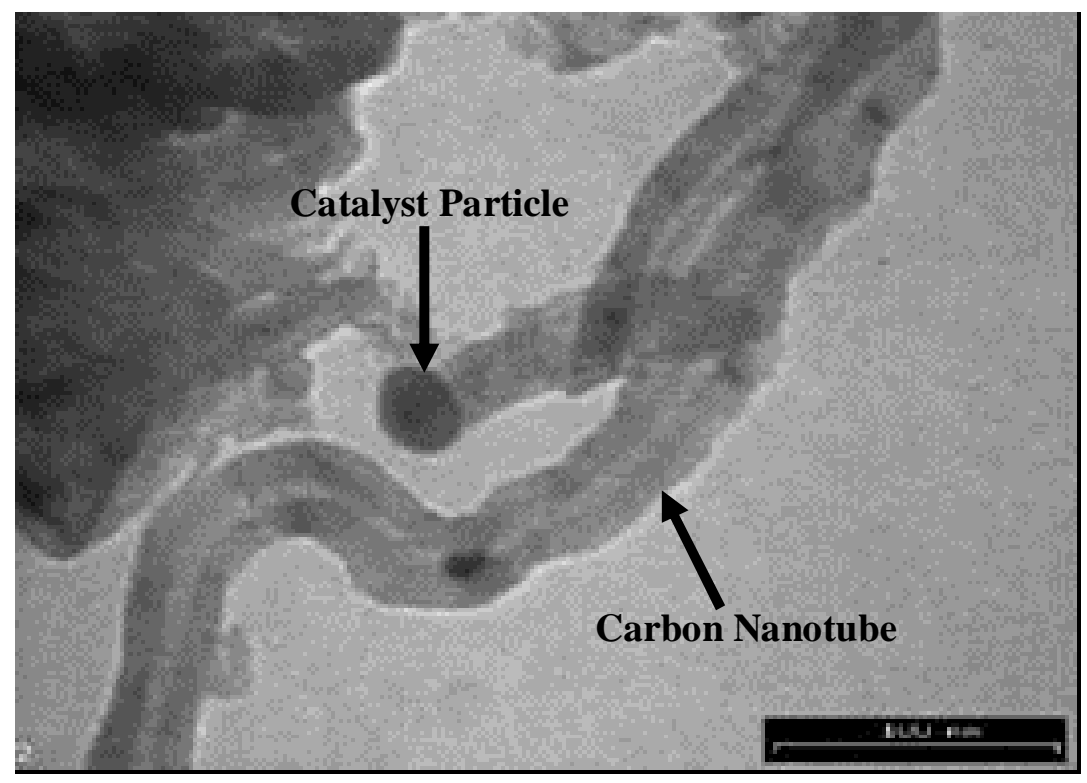

Fig. 6: The transmission electron microscope image of the nanotube produced on $\mathrm{Cu} / \mathrm{Ni}$ supported on $\mathrm{TiO}_{2}$ at $998 \mathrm{~K}$ and GHSV of $2700 \mathrm{~h}^{-1}$. 


\section{CONCLUSION}

Hydrogen production is of great significance on seeking a better way to use natural gas resources. Catalytic decomposition of methane to hydrogen and carbon is a technologically simple single step process without energy and material intensive gas separation stages. It produces only hydrogen and solid carbon. It was found that the catalyst activity in the methane decomposition depended on the filamentous carbon formed. The best catalyst obtained was $\mathrm{Cu} / \mathrm{Ni}$ supported on $\mathrm{TiO}_{2} . \mathrm{TiO}_{2}$ was found to be an effective support for the catalytic decomposition of methane into hydrogen and carbon, giving high activity, attractive carbon nanotube as well as the longest catalyst lifetime.

\section{ACKNOWLEDGMENT}

The authors acknowledge the financial support provided by Ministry of Education, Malaysia and Universiti Sains Malaysia under Fundamental Research Grant Scheme (Project: A/C No: 6070014).

\section{LIST OF ABBREVIATIONS}

$\begin{array}{ll}\text { FID } & \text { Flame ionisation detector } \\ \text { GC } & \text { Gas chromatograph } \\ \text { GHSV } & \text { Gas hourly space velocity } \\ \text { PB } & \text { Pressure build up. When the inlet pressure exceeds } 1 \mathrm{~atm} \\ \text { TCD } & \text { Thermal conductivity detector } \\ \text { TEM } & \text { Transmission electron microscope } \\ V_{p} & \text { Total pore volume } \\ \text { XRD } & \text { X-ray diffraction }\end{array}$

\section{REFERENCES}

[1] N.Z. Muradov, " $\mathrm{CO}_{2}$-free production of hydrogen by catalytic pyrolysis of hydrocarbon fuel”, Energy Fuels, Vol. 12, No. 1, Jan. 1998.

[2] V.V. Chesnokov, V.I. Zaikovskii, R.A. Buyanov, V.V. Molchanov, L.M. Plyasova, "Morphology of carbon from methane on nickel-containing catalysts", Catalysis Today, Vol. 24, No. 3, pp. 265-267, June 1995.

[3] L.B. Avdeeva, O.V. Goncharova, D.I. Kochubey, V.I. Zaikovskii, L.M. Plyasova, B.N. Novgrodov, and Sh.K. Shaikhutdinov, "Coprecipitated Ni-alumina and Ni-Cu-alumina 
catalysts of methane decomposition and carbon deposition. II. Evolution of the catalysts in reaction”. Applied Catalysis A: General, Vol. 141, No. 1-2, pp. 117-129, 4 July 1996.

[4] V.B. Fenelonov, A.Yu. Derevyankin, L.G. Okkel, L.B. Avdeeva, V.I. Zaikovskii, E.M. Moroz, A.N. Zalanov, N.A. Rudina, V.A. Likholobov, "Structure and texture of filamentous carbons produced by methane decomposition on Ni and Ni-Cu catalysts". Carbon, Vol. 35, No. 8, pp. 1129-1140, April 1997.

[5] V.N. Parmon, G.G. Kuvshinov, V.A. Sadykov, and V.A. Sobyanin, "New catalysts and catalytic processes to produce hydrogen and syngas from natural gas and other light hydrocarbons". In Proceedings of the 5th international Natural gas Conversion Symposium, Giardini Naxos - Taormina, Italy, Sept. 20-25, 1998. A. Parmaliana, D. Sanfilippo, F. Frusteri, A. Vaccani, and F. Arena, Eds., pp. 677-684, Amestardam, Holand, 1998.

[6] S. Takenaka, H. Ogihara, I. Yamanka, and K. Otsuka, "Decomposition of methane over supported-Ni catalysts: effects of the supports on the catalytic life time". Applied Catalysis A: General, Vol. 217, No. 1-2, pp. 101-110, Sept. 2001.

[7] F. Solymosi, A. Erdoheyli, , J. Cserenyi and A. Felegi, "Decomposition of $\mathrm{CH}_{4}$ over supported Pd catalysts". Journal of Catalysis, Vol. 147, No. 1, pp. 272-278, May 1994.

[8] G. Boskovic and K.J. Smith, "Methane homologation and reactivity of carbon species on supported Co catalysts". Catalysis Today, Vol. 37, No. 1, pp. 25-32, July 1997.

[9] P. Chen, H.-B. Zhang, G. -D. Lin, Q. Hong and K.R. Tsai, "Growth of carbon nanotubes by catalytic decomposition of $\mathrm{CH} 4$ or $\mathrm{CO}$ on a Ni-MgO catalyst". Carbon, Vol. 35, No. 10-11, pp. 1495-1501, April 1997.

[10] X. Zhang, J. Liu, Y. Jing, and Y. Xie, "Support effects on the catalytic behavior of $\mathrm{NiO} / \mathrm{Al}_{2} \mathrm{O}_{3}$ for oxidative dehydrogenation of ethane to ethylene". Applied Catalysis A: General, Vol. 240, No. 1-2, pp. 143-150, Feb. 2003.

[11] T. Zhang, and M.D. Amiridis, "Hydrogen production via the direct cracking of methane over silica-supported nickel catalysts". Applied Catalysis A: General, Vol. 167, No. 2, pp. 161172, Feb. 1998.

[12] M.A. Ermakova, D.Yu. Ermakov, A.L. Chuvilin, and G.G. Kuvshinov, "Decomposition of methane over iron catalysts at the range of moderate temperatures: the Influence of structure of the catalytic systems and the reaction conditions on the yield of carbon and morphology of carbon filaments". Journal of Catalysis, Vol. 201, No. 2, pp 183-197, July 2001.

\section{BIOGRAPHIES}

Abdul Rahman Mohamed is an Associate Professor and the dean of the school of chemical engineering, Universiti Sains Malaysia. He got his Ph.D. from University of New Hampshire, USA in the area of chemical reaction engineering. His research interest is in the area of chemical reaction engineering and air pollution control.

Sharif Hussein Sharif Zein is a lecturer in the school of chemical engineering, Universiti Sains Malaysia. He got his Ph.D. from Universiti Sains Malaysia in the area of reaction engineering and catalysis. His research interest is in the field of reaction engineering and catalysis, natural gas processing and catalyst development. 